\title{
The Effect of High Temperature Roasted Coffea liberica on Physiological and Histological Structure of Mice's Kidney
}

\author{
Ivolanesky Putri Widodo', Syamsurizal' ${ }^{2, *}$, Diah Tri Utami ${ }^{1}$ \\ 'Pharmacy Department, Faculty of Sains and Technology, Jambi University, Jambi, Indonesia \\ ${ }^{2}$ Chemistry Department, Faculty of Teacher Training and Education, Jambi University, Jambi, Indonesia
}

\begin{abstract}
Numerous varieties of coffee, such as robusta, arabica, gayo and etcetera, was made in order to fulfill the needs of its lovers. In Tungkal, Jambi, Liberica coffee was recently discovered and the chemical reactions during roasting process produces several components, which are caffeine, chlorogenic acid, monosaccharides and others, to create a unique flavor as the identity. Unique flavor of Liberica coffee is obtained from the high temperature roasting process and the components in coffee. This research aims to determine the effect of Liberica coffee (Coffea liberica), concentration ( 0 , $8.000,10.000$ and $12.000 \mathrm{ppm} /$ day) on the physiological and histological structure of the mice's kidney (Mus musculus L.) for 28 days. The results was showed that kidney histological observation of fatty degeneration, tubular swelling, and pyknotic nucleus associated with percentages of renal tubular damage in the control group, P1, P2 and P3 were $0.71 \pm 0.96,4.91 \pm 0.17,5.82 \pm 0.21$ and $9.01 \pm 0.13$ indicating low damage $(<50 \%)$ and liberica coffee does not affect physiological function, such as creatinine level.
\end{abstract}

Keywords : Liberica coffee, kidney, histological

\section{INTRODUCTION}

The evolution of human civilization, change behavior patterns of society to drink coffee. Based on data released by the International Coffee Organization, coffee consumption in Indonesia increased by $5-6 \%$ every year. In 2014 , the number of coffee consumption reached $149.039 / 60 \mathrm{~kg}$, in 2015 the number of coffee consumption was $151.822 / 60 \mathrm{~kg}$, and increased in 2016 to $155.713 / 60 \mathrm{~kg}$. Coffee is a commodity that has been cultivated more than 50 countries. Numerous varieties of coffee, such as robusta, arabica, gayo and etcetera, was made in order to fulfill the needs of its lovers. Liberica coffee was discovered lately as a new variety of coffee from Tungkal, Jambi.

The taste of coffee is generally determined by the roasting process as in coffee Liberica which has stronger flavor characteristic, taste and thicker color when roasting at $230^{\circ} \mathrm{C}$. The chemical components of the coffee will change as well if it is being roasted for quite long. Coffee contains

Submitted: September 18, 2018

Revised: December 12, 2018

Accepted: December 18, 2018

*Corresponding author: syamsurizal68@gmail.com 
components such as caffeine, chlorogenic acid, trigonelline, carbohydrates, amino acids, fats, organic acids, caffeol (volatile aroma) and minerals (Higdon and Frei, 2006). Dominant acid groups, such as chlorogenic acid in coffee beans are $8 \%$ and reduced to $4.5 \%$ during roasting process, it turned into caffeic acid and quinic acid (Yusianto, 2014). Based on previous research from Perdana, et al., (2018) caffeine in green liberica coffee beans is $0.173 \%$, while the liberica coffee has been roasted at $230^{\circ} \mathrm{C}$ is $0.126 \%$ and chlorogenic acid not found after roasting at $230^{\circ} \mathrm{C}$, but there is other component like trigonelline and nicotinic acid after roasting process.

Caffeine in coffee does not decrease significantly but a sublimation process occurs. The roasting process produces several compounds such as trigonelline which produce various compounds including nicotinic acid (3\%) and volatile compounds such as pyrol $(3 \%)$, pyridine (46\%), pyrazine, and methyl nicotinic. In humans, nicotinic acid works as a coenzyme in various metabolic processes. Fast roasting produces coffee with a higher trigonelline content than slow roasting (Farah, 2012).

The chemical reaction of the coffee will change coffee constituents during roasting process that may affect the organs and indicate detrimental effect for the health of kidney that becomes the main filtration organ. Coffee constituents interact with kidney as excretory organs and has adverse renal effect derived from coffee remains and other unknown components on body.

Ismail, et al., (2015) reported histological rats kidney research for 30 days divided into a control group, Turkish coffee roasting $\left(210^{\circ} \mathrm{C}-220^{\circ} \mathrm{C}\right)$, dark Turkish roasted coffee $\left(230^{\circ} \mathrm{C}-250^{\circ} \mathrm{C}\right)$, instant coffee and arabic coffee which showed that in the control group it looked normal, in the Turkish coffee roasting $\left(210^{\circ} \mathrm{C}-220^{\circ} \mathrm{C}\right)$ group and instant coffee group there was mild glomerular and tubular cell degeneration, and the dark Turkish roasted coffee group and the Arab coffee group showed normal conditions in rats kidney cells. According to research from Islam, et al., (2016) giving 5\% coffee, $10 \%$ coffee, $10 \%$ alcohol, $5 \%$ alcohol $+5 \%$ coffee, $10 \%$ alcohol $+10 \%$ coffee, respectively showed no lesions in the renal parenchyma but in mice who receive alcohol or coffee at a level of $10 \%$ there is a reactive infiltration of cells and mild bleeding so that higher doses of alcohol or coffee can damage kidney function. According to Umoh and Jimmy (2017), giving caffeinated and caffeinated coffee at a dose of $5 \mathrm{mg}, 10 \mathrm{mg}$ and $15 \mathrm{mg}$ per $\mathrm{kg}$ of body weight can increase the risk of interstitial tubules and renal glomerular rats.

The purpose of this research is to determine the effect of high temperature roasted coffee Liberica (Coffea liberica) on physiological determined on serum creatinine levels and histological structure of kidney mice (Mus musculus L.) for 28 days.

\section{MATERIALS AND METHODS}

\section{High temperature roasted Liberica coffee preparation}

The coffee powder that will be used comes from Liberica coffee beans roasted at $230^{\circ} \mathrm{C}$ in 15 minutes. Then Liberica coffee powder is brewed with $50 \mathrm{~mL}$ of hot water. Next, give $0.5 \mathrm{~mL}$ orally in experimental animals.

\section{Animal preparation test}

Fourty-eight Male white mice weighing 20-30 grams were placed in a cage divided randomly into 4 groups, acclimatized for one week with standard feeding and drinking in an ad libitum. After that, each group of mice received treatment for 28 days, group I, the control group was given standard and white water (C), group II was Liberica coffee 8.000 $\mathrm{ppm} /$ day (P1), group III was given Liberica coffee $10.000 \mathrm{ppm} /$ day (P2), and group IV namely giving Liberica coffee 12.000 ppm/day (P3). After being treated for 28 days, the mice were turned off by cutting the jugular vein of the mice neck. 


\section{Measurement of serum creatinine level}

Mice blood is taken by cutting the carotid artery on the left neck and then the blood is collected with a test tube. Blood is left for 15 minutes, then centrifuged for 10 minutes at a speed of $3000 \mathrm{rpm}$ so that serum is obtained from the blood. Serum piped as much as $0.5 \mu \mathrm{L}$ put into a test tube then mixed with $1 \mathrm{~mL}$ of working reagent solution, homogenized. Measurements were carried out using a UV spectrophotometer at a wavelength of $510 \mathrm{~nm}$.

\section{Histological preparations}

After being treated for 29 days, the mice were turned off by cutting the jugular vein of the mice neck. Next, surgery was carried out to take samples of the right and left kidneys, the kidneys were cleaned with $0.9 \% \mathrm{NaCl}$ and measured and weighed. Then made kidney histology preparations including stages of fixation, dehydration, clearing, infiltration, embedding, sectioning, staining, and mounting. The results of the incision are stained with a standard stain of Hematoxylin Eosin (HE) (Bacha and Bacha., 2000).

\section{Data analysis}

Quantitative data were analyzed using one-way analysis of variance (ANOVA) with a significance level of 5\% to determine the significant differences between treatments using SPSS 23 software (SPSS Inc., Chicago, USA).

\section{RESULTS}

\section{Serum creatinine level}

Based on observations on excretion organ physiology, namely: kidney mice, showed an average serum creatinine level after being given Liberica coffee for 28 days can be seen in (Table 1).

Based on the results of statistical analysis of serum creatinine of mice, that were tested parametric using One Way ANOVA. The results of the One Way ANOVA test is $p=0.130(\alpha>0.05)$ showed that the serum creatinine level of mice was not significantly different, which means that there was no effect of high temperature roasted coffee on the serum creatinine levels of mice. Serum creatinine levels after being given Liberica coffee for 28 days experienced changes from the control group. Liberica coffee given group with concentration variance did not change significantly. In the control group, serum creatinine levels were $0.21 \mathrm{mg} / \mathrm{dL}$, group P1 had a lower serum creatinine level of $0.14 \mathrm{mg} / \mathrm{dL}$, group P2 had serum creatinine levels of $0.35 \mathrm{mg} / \mathrm{dL}$, and group $\mathrm{P} 3$ had serum creatinine levels of $0.16 \mathrm{mg} / \mathrm{dL}$. This low serum creatinine can be caused by a mildly reversible damage to the kidneys.

\section{Kidney Histology}

Based on observations of kidney histology in tubuli cells in the form of degrees of damage to cells after being given Liberica coffee for 28 days can be seen in (Table 2).

Table 1. Average serum creatinine levels of mice after 28 days.

\begin{tabular}{ccccc}
\hline \multirow{2}{*}{ Treatment } & \multicolumn{4}{c}{ Serum Creatinine Levels (mg/dL) } \\
\cline { 2 - 5 } & Control & P1 & P2 & P3 \\
\hline 1 & 0.28 & 0.14 & 0.14 & 0.07 \\
2 & 0.21 & 0.14 & 0.5 & 0.28 \\
3 & 0.07 & 0.07 & 0.21 & 0.14 \\
4 & 0.28 & 0.21 & 0.57 & 0.14 \\
\hline Mean \pm SEM & $0.21^{\text {ns }} \pm 0.05$ & $0.14^{\text {ns }} \pm 0.02$ & $0.35^{\text {ns }} \pm 0.10$ & $0.16^{\text {ns }} \pm 0.04$ \\
\hline
\end{tabular}


Indonesian Journal of Cancer Chemoprevention, February 2019

Tabel 2. Degree of damage to the kidney proximal tubular cells.

\begin{tabular}{ccccc}
\hline \multirow{2}{*}{ Treatment } & \multicolumn{4}{c}{ Percentage of Kidney Tubular Cell Damage } \\
\cline { 2 - 5 } & Control & P1 & P2 & P3 \\
\hline 1 & 1.74 & 7.9 & 9.96 & 13 \\
2 & 0 & 5.42 & 7.28 & 6.8 \\
3 & 1.1 & 3.66 & 2.32 & 8.74 \\
4 & 0 & 2.68 & 3.74 & 7.5 \\
\hline Mean \pm SEM & $0.71^{\mathrm{a}} \pm 0.96$ & $4.91^{\mathrm{b}} \pm 0.17$ & $5.82^{\mathrm{b}} \pm 0.21$ & $9.01^{\mathrm{b}} \pm 0.13$ \\
\hline Scoring & 0 & 1 & 1 & 1 \\
\hline
\end{tabular}

Each treatment group showed a difference in the average degree of cessation of kidney proximal tubular cells in mice based on the mean and standard deviation calculations. In the control group, P1, P2 and P3 the percentage of chancellors has not reached $10 \%$. According to the Venient, et al., method, the percentage of cuscuses below $50 \%$ received a score of 1 indicating low tubular cell damage. Kruskal-Wallis non parametric statistical analysis was conducted to determine differences in each treatment group. based on the results of the Kruskal-Wallis test, $p=0.017 \quad(\alpha<0.05)$ showed that the average degree of damage to the proximal renal tubular cells was different between treatment groups. Mann-Whitney U follow-up test was conducted to find out the differences in each treatment group that can be seen in (Table 2).

Observations on renal histology changes were carried out microscopically with hematoxylin and eosin (HE) staining seen using a binocular light microscope with a magnification of $40 \times 10$ after being given Liberica coffee for 28 days from each control treatment group, P1, P2 and P3. The histological features of mouse kidney can be seen in Figure 1.

Figure 1 shows the tubule cells of mice starting from the control group which were treated with standard feed and drink which did not experience damage and looked normal (A). The P1 group which was given Liberica coffee with a concentration of
$8.000 \mathrm{ppm}$ for 28 days (B) showed that tubular cells experienced swelling (vacuolization) and that several cell nuclei experienced picnotics. In the P2 group which was given Liberica coffee with a concentration of 10.000 ppm for 28 days (C), the cell nucleus experienced pyknotic and swelling in the tubular cells. In the P3 group which was given Liberica coffee with a concentration of $12.000 \mathrm{ppm}$ for 28 days (D) it was seen that the tubule cells were getting bigger and there was damage to the core where there was no visible limit on the cell nucleus.

\section{DISCUSSION}

The treatment of high temperature roasted Liberica coffee showed that creatinine levels are still in the normal range where according to Jaffe's normal value for serum creatinine. According to Helmi, et al., (2016) by giving ethanol extract of coffee leaves at a dose of $100 \mathrm{mg} / \mathrm{kgBW}, 200$ $\mathrm{mg} / \mathrm{kgBB}$, and $400 \mathrm{mg} / \mathrm{kgBB}$ which showed that between dose and the length of time of giving on serum creatinine level was no interaction effect because the ethanol extract of coffee parasite leave can affect the serum creatinine and serum creatinine levels respectively $0.1264 \pm 0.1990 \mathrm{~g} /$ $\mathrm{dL}, 1.777 \pm 0.0214 \mathrm{mg} / \mathrm{dL}, 0.1057 \pm 0.0177 \mathrm{mg} / \mathrm{dL}$, $0.1435 \pm 0.0180 \mathrm{mg} / \mathrm{dL}$. In accordance with Islam, et al., (2015), creatinine levels in mice were divided into groups of coffee and alcohol, wherein the 

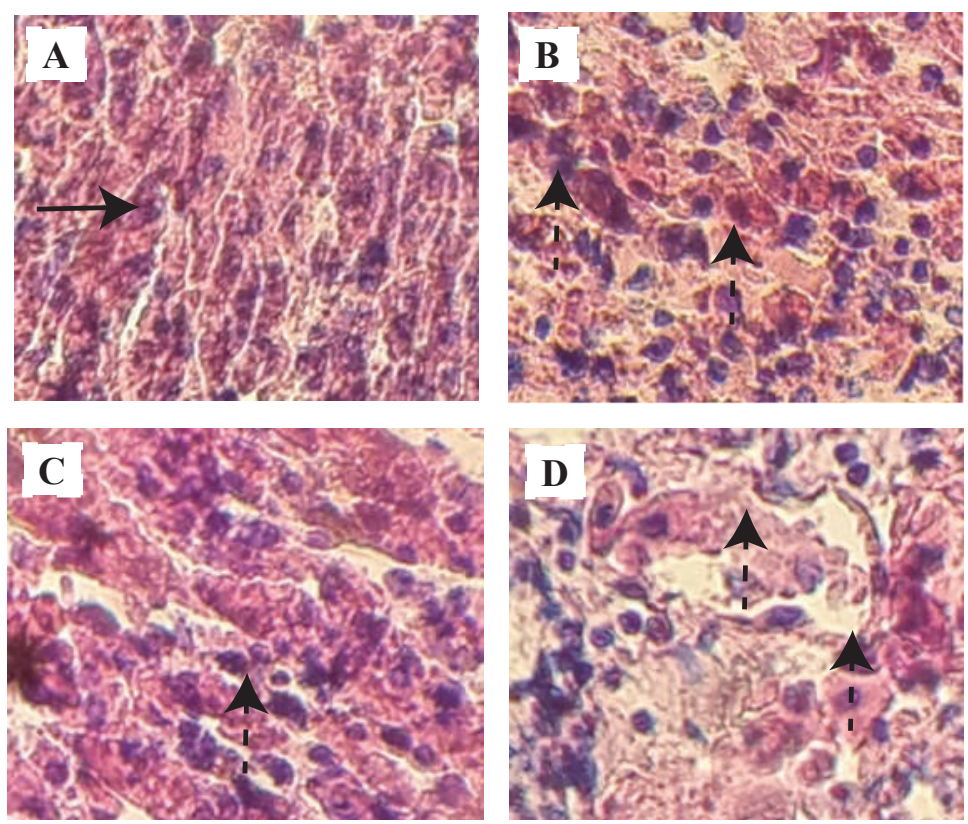

Figure 1. Picture of kidney histology of mice with $40 \times 10$ magnification. Effect of Liberica coffee for 28 days with control group (A), $8.000 \mathrm{ppm} /$ day (B), $10.000 \mathrm{ppm} /$ day (C), and 12.000 ppm/day (D). A: Normal tubular cell (arrow); B and C: Pyknotic cells and fat degeneration (broken arrows); D: Karyorrhexis cells and fat degeneration (broken arrows). administration of $10 \%$ alcohol increased creatinine levels and the administration of coffee did not show an increase in creatinine levels. Based on those studies, it can be concluded that the administration of coffee does not affect creatinine levels in mice. So, high temperature roasted Liberica coffee treatment shows normal creatinine levels because the glomerulus and tubular cells in the kidney are in normal conditions so they are still able to filter creatinine out of the body. If there are abnormalities in the function of the glomerulus and tubules, it can cause reduced creatinine and urea expenditure, so that creatinine and urea levels in the blood are high (Silbernagl and Lang, 2007).

Research from Panggabean (2017) states that the green liberica coffee beans contain caffeine compounds, chlorogenic acid, caffeic acid, monosaccharides, acetic acid, and citric acid. However, after liberica coffee was roasted at $230^{\circ} \mathrm{C}$, the content of liberica coffee beans changed, new compounds appeared namely trigonelline and nicotinic acid which are heat sensitive and the caffeine level in Liberica coffee decrease, it can caused the decrease of adverse effects from caffeine. Consumption of caffeine containing drinks can increase blood pressure because caffeine can stimulate the vasomotor center and stimulate the myocardium to increase blood pressure (Tan and Kirana, 1984). Caffeine is a non-selective adenosine A1 receptor antagonist that can inhibit the renovascular effects of adenosine. Caffeine will bind adenosine compounds in the brain so that the impact on brain activity will increase and cause the spread of epinephrine and adrenaline hormones which will increase heart rate, increase blood pressure, increase blood flow to the muscles. This causes an increase in angiotensin II and increases systemic blood pressure which is transmitted to the glomerulus, which can cause kidney damage. Increased diuresis is also caused by an increase in renal blood flow and glomerular filtration speed as a result of a reduction in normal tubular reabsorption. (Stefanello, et al., 2015). But the effect is reduced according to the declining caffeine levels during the roasting process.

The treatment of high temperature roasted Liberica coffee in histological structure, degeneration observed in each treatment did not 
occur in all cells, because there are many normal tubular cells and cell nucleus due to degeneration that still occurs in the early stages due to the reduced ability of cells to accumulate incoming water so that the cells appear swollen.

Degeneration is a sign of the start of cell damage due to toxic substances with the condition of cells that lose normal structure to cell death. Cell degeneration begins with hydropic degeneration, parenchymal degeneration, and necrosis which is divided into stages of pyknosis, karyorrhexis, and karyolysis (Price and Wilson, 2005). Tubular cells that are swollen can be caused by various compounds because tubular cells will come into direct contact with compounds that are reabsorbed and occur when cells are deprived of oxygen so that metabolic processes that should be good will be disrupted (Mitchell and Cotran, 2007). But the indication of this damage is still reversible or can return to normal again if the oxygen demand in cells is met, tubular cells that experience swelling will return to normal. Decreased renal function and structure can also be mediated by arterial hypertension, glomerular capillary hypertension, hyperfiltration, oxidative stress, inflammation, and lipid disorders and other factors (Cho, et al., 2010).

Nicotinic acid compounds have an effect on improving kidney function by an increase in glomerular filtration rate (Kang, et al., 2013). Research from Cho, et al., (2010), administration of nicotinic acid in rats can improve kidney tissue lipid metabolism, improve kidney function and structure, and reduce interstitial tubular injury in renal histology by reducing renal swelling. Nicotinic acid is also proven to be an effective agent for reducing triglycerides and increasing High Density Lipoprotein (HDL) (NCEP, 2002). Supported by the opinion of Ganji, et al., (2009), that nicotinic acid is known to increase HDL, reduce triglycerides and have strong antioxidant and anti-inflammatory potential. So that tubular cell damage in the kidney histology seen in Figure
1 can be reduced due to nicotinic acid compounds that have anti-inflammatory activity.

Trigonelline can also improve kidney function in rats through its anti-inflammatory activities (Sayed, et al., 2012). Supported by research from Zhou, et al., (2013) that trigonelline compounds derived from plants containing alkaloids have hypoglycemic, antiseptic, anticarcinogenic and commonly used for the treatment of diabetes in China. One of the factors that decrease kidney function and structure is lipid disturbance, if a lot of accumulated lipids in the kidneys will accelerate kidney disease in diabetic nephropathy and the glomerular aging process (Cho, et al., 2010). The study by Lestari, et al., (2017) showed changes in renal histology of rats given robusta coffee with a dose of $0.36 \mathrm{~mL}, 0.72 \mathrm{~mL}, 1.44 \mathrm{~mL}, 2.16 \mathrm{~mL}$ for 28 days with the presence of thyroidization in the tubular cells which grew larger each dose increase. Supported by research from Ismail, et al., (2015) that rat kidney histology given dark roasting of turkey coffee for 30 days showed a normal condition in rat kidney cells while rat kidney histology given turkey coffee roasting medium for 30 days showed a mild degeneration of glomerular and tubular cells. Nicotinic acid and trigonelline contained in high temperature roasted coffee Liberica will help suppress damage caused by toxic compounds found in coffee. Therefore, the histological changes in the treatment group observed did not appear to differ much from the control group and kidney tubular cell damage was reversible.

\section{CONCLUSION}

The results of the study based on physiological and histological microscopic structures showed that high temperature roasted Liberica coffee does not affect kidney physiology as indicated by normal creatinine levels, and caused changes in renal histological microscopic structure with low levels of tubular cell damage $(<50 \%$ of necrotic cells) in the administration of Liberica coffee with concentrations of 8.000, 10.000, and $12.000 \mathrm{ppm}$. 


\section{REFERENCES}

Bacha, W.J.J. and Bacha, L.M., 2000, Color Atlas of Veterinary Histology, 2nd ed, Philadelphia: Lippincott Williams \& Wilkins.

Cho, K.H., Kim, H.J., Kamanna, V.S. and Vaziri, N.D., 2010, Niacin Improves Renal Lipid Metabolism and Slows Progression in Chronic Kidney Disease, Biochim. Biophys. Acta, 1800(1), 6-15.

Ganji, S.H., Qin, S., Zhang, L., Kammana, V.S. and Kashyap, M.L., 2009, Niacin Inhibits Vascular Oxidative Stress, Redox-sensitive Genes, and Monocyte Adhesion to Human Aortic Endothelial Cells, Atherosclerosis, 202(1), 68-75.

Helmi, A., Dillasamola, D. and Putri, W., 2016, Characterization and Sub Acute Toxicity Ethanol Extracts from Leaves of coffee Parasites (Scurrula ferruginea Jack Dance) to the activity of SGPT and Serum Creatinine Levels male white mice, Res. J. Pharm., Biol. Chem. Sci., 7(3), 2675-2683.

Higdon, J.V. and Frei, B., 2006, Coffee and Health: a Review of Recent Human Research, Crit. Rev. Food Sci. Nutr., 46(2), 101-123.

Islam, M.T., Islam, M.K., Hossain, M.Z. and Wares, M.A., 2015, Kidney Histotexture and Serum Creatinine Level in Response to Concurrent Administration of Alcohol and Coffee in Mice, Bangladesh Vet., , 32(2), 42-47.

Ismail, M.S., Elmaadawy, A.A., Saad, H.H. and Al-Qahiz, N.M., 2015, Impacts of Different Preparations of Coffee on Body Weight, Serum Uric Acid and Liver Enzymes in Experimental Rats, J. Med. Med. Sci., 3(7), 292-300.

Kang, H.J., Kim, D.Y., Lee, S.M., Kim, K.H., Han, S.H., Nam, H.K., et al., 2013, Effect of Lowdose Niacin on Dyslipidemia, Serum Phosphorus Levels and Adverse Effects in Patients with Chronic Kidney Disease, Kidney Res. Clin. Pract., 32, 21-26.

Lestari, D.Y., Isbandiyah, I., Marcianto, A.R., Savithri, F. and Rayyan, 2017, Acrylamide in Robusta Coffee on Blood Pressure, Urine Production and Renal Histopathological Change in White Male Rats, Adv. Health Sci. Res., 2, 247-253.

Mitchell, R.N., Cotran, R.S., 2007, Jejas, Adaptasi, dan Kematian Sel. In: Kumar, V., Cotran, R.S., Robbins, S.L, ed., Buku Ajar Patologi Robbins
Volume 1, 7th Ed, Jakarta: EGC. pp.26-27.

Farah, A, 2012, Coffee: Emerging Health Effects and Disease Prevention, 1st Ed, New Jersey: Blackwell Publishing Ltd.

National Cholesterol Education Program (NCEP) Expert Panel on Detection, 2002, Evaluation, and Treatment of High Blood Cholesterol in Adults (Adult Treatment Panel III), Circulation, 106(25), 3143-421.

Panggabean, Y., 2017, Karakterisasi Biji Kopi Liberika (Coffea liberica) dengan Memvariasikan Suhu dalam Proses Roasting Menggunakan Metode Spectroscopy dan Scanning Calorimetry, Essay, Universitas Jambi, Jambi.

Perdana, B.M., Manihuruk, R., Ashyar, R., Heriyanti and Sutrisno, 2018, Evaluation of the Effect of Roasting Process on the Energy Transition and the Crystalline Structures of Arabica, Robusta, and Liberica Coffee from Jambi Indonesia, IOP Conf. Ser. Mater. Sci. Eng., 345, 012021. doi:10.1088/1757-899X/345/1/012021

Price, S.A. and Wilson, L.M., 2005, Patofisiologi: Konsep Klinis Proses-proses Penyakit, 6th ed, Jakarta: EGC.

Sayed, A.A., Khalifa, M. and Abdel-Latif, F.F., 2012, Fenugreek Attenuation of Diabetic Nephropathy in Alloxan-diabetic Rats: Attenuation of Diabetic Nephropathy in Rats, J. Physiol. Biochem., 68(2), 263-269.

Silbernagl S. and Lang F, 2007, Color Atlas of Pathophysiology, Jakarta: EGC.

Stefanello, N., Vieira, J. M., Schmatz, R. and Passamonti, S., 2015, Chlorogenic acid, caffeine and coffe reverse damages in liver, kidney and pancreas parameters of diabetic rats, J. Diabetes Health, 108, 214-228.

Umoh, I.U. and Jimmy, E.O., 2017, A comparative Histopathological Effect of Caffeinated and Decaffeinated Coffee on the Histomorphology of the Kidney of Adult Male Albino Wistar Rats, J. Pharm. Biol. Sci., 12(3), 62-66.

Yusianto and Dwi, N., 2014, Mutu Fisik dan Citarasa Kopi Arabika yang Disimpan Buahnya Sebelum di-Pulping, Pelita Perkebunan, 30(2), 137-158.

Zhou, J., Chan, L. and Zhou, S., 2012, Trigonelline : a Plant Alkaloid with Therapeutic Potential for Diabetes and Central Nervous System Disease, Curr. Med. Chem., 19(21), 3523-3531. 